\title{
COMPARATIVE ANALYSES OF DIAGNOSTIC METHODS IN KNEE INJURIES
}

\author{
Dzoleva-Tolevska Roza, ${ }^{1}$ Poposka Anastasika, ${ }^{1}$ Georgieva Daniela, \\ Bozinovski Zoran, ${ }^{1}$ Nanceva Jasminka, ${ }^{1}$ Gjoshev Stojan ${ }^{2}$ \\ ${ }^{1}$ Univerity Clinic for Orthopaedic Surgery, Skopje, R. Macedonia \\ ${ }^{2}$ University Clinic for Abdominal Surgery, University “Ss Cyril and Methodius”, Skopje, R. Macedonia \\ Primljen/Received 20. 01. 2016. god. \\ Prihvaćen/Accepted 02. 03. 2016. god.
}

Abstract: Objective: This study is analyzing the role and significance of the three diagnostic methods (clinical diagnosis, magnetic resonance imaging (MRI) and arthroscopy), in establishing accurate diagnosis in knee injuries. The goal is to determine the diagnostic accuracy of each diagnostic method, using arthroscopy as gold standard.

Material and Methods: We examined 70 patients with knee injuries. Clinical diagnosis was established using patient's history and positive clinical tests for meniscal lesions, ACL injury and articular cartilage lesions. All patients underwent MRI on a $1.5 \mathrm{~T}$ magnet for MRI diagnosis. This was followed by arthroscopy for making the final diagnosis.

Results: We analyzed the results of clinical tests for meniscal, ligamentous and articular cartilage injuries of the patients in both groups. Validity of the clinical tests was compared to the results got from MRI and arthroscopy. Accuracy of clinical diagnosis versus MRI diagnosis for medial( $69.6 \%$ vs. $68.5 \%)$ and lateral ( $84 \%$ vs. $82.6 \%)$ meniscal lesions was almost identical. Accuracy of clinical diagnosis compared with the accuracy of MRI diagnosis for ACL injuries was higher $(91.3 \%$ vs. $81.4 \%)$. Accuracy ( $85.5 \%$ vs. $72.8 \%)$ of clinical diagnosis versus MRI diagnosis for articular cartilage lesions was better.

Conclusion: Affirmation of clinical diagnosis in this study is a result of usage of standard clinical signs and tests which are fundamental in establishing clinical diagnosis of knee injuries. MRI is a diagnostic method which enriches the diagnostic process. Arthroscopy is defined as superior diagnostic method, also a gold standard for comparison of the other two diagnostic methods.

Key words: knee injuries, clinical examination, MRI, arthroscopy.

\section{INTRODUCTION}

Diagnosis of knee injuries is established using clinical examinations and magnetic resonance imaging (MRI) of the injuried knee. Both methods are used for obtaining necessary data in order to decide whether to perform arthroscopy or not.

Patient's history gives information on the mechanism of the injury, localization of the pain, swelling, limitations etc. Several clinical tests are used for diferentiation if there are a meniscal, ligamentous or cartilage injuries $(1,2,3,4,5,6,7,8)$. Knee injuries are common. They often can be combined and sometimes is difficult to establish a precise clinical diagnosis of the injuried tissue $(9,10,11,12,13,14)$. MRI is an additional diagnostic method since it offers useful data in the final decision on performing arthroscopy (9). Positive clinical and MRI diagnosis for knee injuries gives us an indication for arthroscopy. Arthroscopy is a gold standard for diagnosis and at the same time it is an operative method used for minimal invasive treatment of the injured knee $(10,15,16,17,18)$.

\section{AIM}

The aim of this study was to determine the accuracy of clinical and MRI diagnosis in comparison to arthroscopy for detecting knee injuries. It was also our aim to found out whether MRI diagnosis has an impact on the surgeon's decision for the choice of treatment.

\section{MATERIAL AND METHODS}

We have examined 70 patients with knee injuries, $50(71.4 \%)$ of them were male and $20(28.6 \%)$ female, with avarage age of $35 \pm 15$ years. Patients with meniscal, ACL or cartilage injury were analysed in this 
study. Inclusion criteria were as follows: patients with established clinical diagnosis of knee injury, MRI of the injuried knee and arthroscopy.

Patients with acute knee injury, intra-articular fractures, loose bodies, disecant osteochondritis, degenerative osteoarthritis and inflamations were excluded from the study.

Clinical diagnosis was established using patient's history and positive clinical tests for meniscal injuries (McMurray and Apley), ACL injury (anterior drawer test, Lachman test and pivot shift test) and articular cartilage injuries (McMurray test for medial and lateral condyl, patella tests). All patients underwent MRI on a $1.5 \mathrm{~T}$ magnet for MRI diagnosis. This was followed by arthroscopy for making the final diagnosis. The same surgeon has performed clinical as well as arthroscopic diagnosis of the injured knee.

Clinical and MRI diagnoses were correlated with arthroscopic diagnosis which was used as a gold standard. To determine the credibility of the clinical examinations and MRI, sensitivity, specificity, positive predictive value (PPV), negative predictive value (NPV) and accuracy were assessed. We were using statistical programSPSSforWindows for analyzing the data.

\section{RESULTS}

From 70 patients with knee injuries, 55 were with clinical diagnosis of meniscal lesions, 26 were with clinical diagnosis of ACL injury and51 were with clinical diagnosis of articular cartilage lesion.

\section{Meniscal lesions}

Among 55 patients with clinically diagnosed meniscal lesion 44 were with medial meniscal lesion and
11 with lateral meniscal lesion. Arthroscopy confirmed accuracy of clinical diagnosis in 32 patients $(72 \%)$ or (44 vs. 32) with medial meniscal lesion, and 8 patients (72.7\%) or (11 vs. 8) with lateral meniscal lesion. From 56 patients with medial meniscal lesion on MRI, arthroscopy confirmed the diagnosis in 34 patients $(60.7 \%)$ or (56 vs. 34$)$ and from 10 patients with lateral meniscal lesion arthroscopy confirmed the diagnosis in 6 patients $(60 \%)$ or ( 10 vs. 6$)$.

The sensitivity of clinical diagnosis versus MRI diagnosis for medial meniscus $(79.9 \%$ vs. $79.5 \%)$ was identical. The specificity of clinical diagnosis was better in comparison to MRI (58.1\% vs 38.1\%). Positive predictive values $(69.8 \%$ vs. $69.6 \%)$ and negative predictive values (69.2\% vs. $69.2 \%)$ for medial menuscus were the same (Table 1).

The sensitivity of clinical diagnosis versus MRI diagnosis for lateral meniscus (50\% vs. $40 \%$ ) was better. The specificity of clinical diagnosis in comparison to MRI ( $92.7 \%$ vs. $92.7 \%$ ) was identical. Positive predictive values $(63.6 \%$ vs. $60 \%)$ and negative predictive values $(87.9 \%$ vs. $85.5 \%)$ for lateral menuscus were the same.

Diagnostic accuracy of clinical diagnosis was higher in comparison to MRI diagnosisfor medial meniscal lesion $(69.6 \%$ vs. $68.5 \%)$ and for lateral meniscal lesion ( $84 \%$ vs. $82.6 \%$ ) (Table 2).

\section{ACL injury}

ACL injury was clinically diagnosed in 26 patients.Arthroscopy confirmed the clinical diagnosis in 25 patients $(96.15 \%)$. From 26 patients with ACL injury on MRI, arthroscopy confirmed the diagnosis in 22 patients $(84.61 \%)$.

The sensitivity ( $83.3 \%$ vs. $71 \%$ ), specificity $(97.4 \%$ vs. $89.7 \%)$, positive predictive values $(96.2 \%$ vs. $84.6 \%)$

Table 1. Statistical methods for medial meniscal lesions

\begin{tabular}{|l|c|c|c|c|}
\hline \multicolumn{1}{|c|}{ Medial meniscus } & McMurray & Apley & ClinicalDg & MRI \\
\hline Sensitivity & $\begin{array}{c}82 \% \\
(95 \% \mathrm{CI})\end{array}$ & $\begin{array}{c}63.1 \% \\
(66.6-90.8)\end{array}$ & $\begin{array}{c}79.9 \% \\
(63.7-88.9)\end{array}$ & $\begin{array}{c}79.5 \% \\
(65.9-85.8)\end{array}$ \\
\hline Specificity & $58.1 \%$ & $62.5 \%$ & $58.1 \%$ & $38.1 \%$ \\
$(95 \% \mathrm{CI})$ & $(40.8-73.6 \%)$ & $(46.9-78.9)$ & $(40.8-73,6)$ & $(25.6-55.4)$ \\
\hline PPV & $70.5 \%$ & $66.7 \%$ & $69.8 \%$ & $69.6 \%$ \\
$(95 \% \mathrm{CI})$ & $(55.8-81.8)$ & $(53.1-82)$ & $(54.9-81.4)$ & $(56.7-81.4)$ \\
\hline NPV & $72 \%$ & $60.6 \%$ & $69.2 \%$ & $69.2 \%$ \\
$(95 \% \mathrm{CI})$ & $(52.4-85.7 \%)$ & $(43.7-75.3)$ & $(50-83.5)$ & $(42.4-87.3)$ \\
\hline LR+ & 1.9 & 1.8 & 1.9 & 1.2 \\
\hline LR- & 0.3 & 0.5 & 0.4 & 0.4 \\
\hline Diagnostic accuracy & $71 \%$ & $64 \%$ & $69.6 \%$ & $68.5 \%$ \\
\hline Area Under Roc curve & 0.7 & 0.6 & 0.7 & 0.7 \\
$(95 \% \mathrm{CI})$ & $0.6-0.8$ & $0.5-0.7$ & $06-0.8$ & $0.5-0.8$ \\
\hline
\end{tabular}


Table 2. Statistical methods for lateral meniscal lesions

\begin{tabular}{|l|c|c|c|c|}
\hline \multicolumn{1}{|c|}{ Lateral meniscus } & McMurray & Apley & ClinicalDg & MRI \\
\hline $\begin{array}{l}\text { Sensitivity } \\
(95 \% \mathrm{CI})\end{array}$ & $\begin{array}{c}53.3 \% \\
(30.1-75.2)\end{array}$ & $\begin{array}{c}50 \% \\
(26.8-73.2)\end{array}$ & $\begin{array}{c}50 \% \\
(26.8-73.2)\end{array}$ & $\begin{array}{c}40 \% \\
(19.8-64.3)\end{array}$ \\
\hline Specificity & $94.4 \%$ & $96.4 \%$ & $92.7 \%$ & $92.7 \%$ \\
$(95 \% \mathrm{CI})$ & $(84.9-98.1)$ & $(87.7-99)$ & $(82.7-97.1)$ & $(82.7-97.1)$ \\
\hline PPV & $72.7 \%$ & $77.8 \%$ & $63.6 \%$ & $60 \%$ \\
$(95 \% \mathrm{CI})$ & $(43.4-90.3)$ & $(45.3-93.7)$ & $(35.4-84.8)$ & $(33.3-83.2)$ \\
\hline $\mathrm{NPV}$ & $87.9 \%$ & $88.3 \%$ & $87.9 \%$ & $85.5 \%$ \\
$(95 \% \mathrm{CI})$ & $(77.1-94)$ & $(77.8-94.2)$ & $(77.1-94)$ & $(73.9-91.9)$ \\
\hline LR+ & 9.6 & 13.7 & 6.9 & 5.5 \\
\hline LR- & 0.5 & 0.5 & 0.5 & 0.6 \\
\hline Diagnostic accuracy & $85.5 \%$ & $86.9 \%$ & $84 \%$ & $82.6 \%$ \\
\hline Area Under Roc curve & 0.8 & 0.8 & 0.8 & 0.7 \\
$(95 \% \mathrm{CI})$ & $(0.7-0,9)$ & $(0.6-0,9)$ & $(0.6-0.9)$ & $0.5-0.9$ \\
\hline
\end{tabular}

Legend: PPV (positive predictive values); NPV (negative predictive values); LR+ (likelihood ratio positive); LR- (likelihood ratio negative); AUC (area under the curve)

Table 3. Statistical methods in LCA injuries

\begin{tabular}{|l|c|c|c|c|c|}
\hline \multicolumn{1}{|c|}{ LCA } & $\begin{array}{c}\text { Anterior } \\
\text { drawer test }\end{array}$ & Lachman & Pivot shift & $\begin{array}{c}\text { Clinical } \\
\text { Dg }\end{array}$ & MRI \\
\hline Sensitivity & $\begin{array}{c}83.3 \% \\
(65.4-92.7)\end{array}$ & $\begin{array}{c}69.4 \% \\
(51.8-82.7)\end{array}$ & $\begin{array}{c}56.5 \% \\
(39.3-72.2)\end{array}$ & $\begin{array}{c}83.3 \% \\
(66.4-92.7)\end{array}$ & $\begin{array}{c}71 \% \\
(53.4-83.9)\end{array}$ \\
\hline $\begin{array}{l}\text { Specificity } \\
(95 \% \mathrm{CI})\end{array}$ & $\begin{array}{c}97.4 \% \\
(86.8-99.5)\end{array}$ & $\begin{array}{c}98.8 \% \\
(89.1-99.9)\end{array}$ & $\begin{array}{c}98.8 \% \\
(89.1-99.9)\end{array}$ & $\begin{array}{c}97.4 \% \\
(86.8-99.5)\end{array}$ & $\begin{array}{c}89.7 \% \\
(76,4-95.9)\end{array}$ \\
\hline PPV & $96.2 \%$ & $97.7 \%$ & $97.2 \%$ & $96.2 \%$ & $84.6 \%$ \\
$(95 \% \mathrm{CI})$ & $(81.1-99.3)$ & $(81.5-99.8)$ & $(78.1-99.7)$ & $(81.1-99.3)$ & $(66.5-93.8)$ \\
\hline NPV & $88.4 \%$ & $80.6 \%$ & $74.5 \%$ & $88.4 \%$ & $79.5 \%$ \\
$(95 \% \mathrm{CI})$ & $(75.5-94.9)$ & $(67.5-89.3)$ & $(61.4-84.3)$ & $(75.5-94.9)$ & $(65.5-88.8)$ \\
\hline LR+ & 32.5 & 55.5 & 45.1 & 32.5 & 6.9 \\
\hline LR- & 0.2 & 0.3 & 0.4 & 0.2 & 0.3 \\
\hline Diagnostic accuracy & $91.3 \%$ & $86.9 \%$ & $81.2 \%$ & $91.3 \%$ & $81.4 \%$ \\
\hline
\end{tabular}

Legend: PPV (positive predictive values); NPV (negative predictive values); LR+ (likelihood ratio positive); LR- (likelihood ratio negative); AUC (area under the curve)

and negative predictive values $(88.4 \%$ vs. $79.5 \%)$ of clinical diagnosis versus MRI diagnosis for ACL tears were better. Same results were also found for clinical tests (anterior drawer test, Lachman test, pivot shift test). In our study anterior drawer test was superior against the other two tests in diagnosing LCA tears (Table 3 ).

Diagnostic accuracy of clinical diagnosis was higher in comparison to MRI diagnosis for ACL injuries (91.3\% vs. 81.4\%) as depicted in Table 3.

\section{Articular cartilage lesions}

We had 51 patients with clinically diagnosed articular cartilage injury. Arthroscopy confirmed the clinical diagnosis in 45 patients $(88.23 \%)$. From 48 patients with articular cartilage injury on MRI, arthroscopy confirmed the diagnosis in 39 patients $(81.25 \%)$.

The sensitivity $(91.8 \%$ vs. $79.6 \%)$, specificity $(70 \%$ vs. $57.1 \%)$, positive predictive values ( $88.2 \%$ vs. $81.3 \%)$ and negative predictive values $(77.8 \%$ vs. $54.5 \%)$ of clinical diagnosis versus MRI for cartilage lesions were better. Diagnostic accuracy of clinical diagnosis was higher in comparison to MRI diagnosis for articular cartilage injuries (85.5\% vs. $72.8 \%$ ) as depicted in Table 4 .

\section{DISCUSSION}

Analyzis of the results in this study coresponds with the results from similar studies exploring this feeld. The conclusions were identical. Authors point out 
Table 4. Statistical methods in articular cartilage injuries

\begin{tabular}{|l|c|c|}
\hline Articular cartilage & Clinical Dg & \multicolumn{1}{c|}{ MRI } \\
\hline $\begin{array}{l}\text { Sensitivity } \\
(95 \% \mathrm{CI})\end{array}$ & $\begin{array}{c}91.8 \% \\
(80.8-96.8)\end{array}$ & $\begin{array}{c}79.6 \% \\
(66.4-88.5)\end{array}$ \\
\hline Specificity & $\begin{array}{c}70 \% \\
(95 \% \mathrm{CI})\end{array}$ & $\begin{array}{c}57.1 \% \\
(36.1-85.5)\end{array}$ \\
\hline PPV & $88.2 \%$ & $81.3 \%$ \\
$(95 \% \mathrm{CI})$ & $(54.8-94.5)$ & $68.1-89.8)$ \\
\hline NPV & $77.8 \%$ & $54.5 \%$ \\
$(95 \% \mathrm{CI})$ & $(54.8-91)$ & $(34.7-73.1)$ \\
\hline LR+ & 3.1 & 1.8 \\
\hline LR- & 0.1 & 0.4 \\
\hline Diagnostic accuracy & $85.5 \%$ & $72.8 \%$ \\
\hline AUC & 0.8 & 0.7 \\
$(95 \% \mathrm{CI})$ & $(0.7-0.9)$ & $(0.5-0.8)$ \\
\hline
\end{tabular}

Legend: PPV (positive predictive values); NPV (negative predictive values); LR+ (likelihood ratio positive); LR- (likelihood ratio negative); AUC (area under the curve)

that clinical examination is more reliable in diagnosing meniscal lesions, ACL tears and articular cartilage lesions, altought previously it was asumed that MRI was essential in establishing accurate diagnosis.

In our study sensitivity ( $79.9 \%$ vs. $79.5 \%)$, specificity (58.1\% vs. $38.1 \%)$, PPV (63.6\% vs. $60 \%)$, NPV $(87.9 \%$ vs. $85.5 \%)$ and accuracy $(69.6 \%$ vs. $68.5 \%)$ of clinical diagnosis versus MRI for medial meniscal lesions were almost identical. Sensitivity (50\% vs. $40 \%$ ), specificity (92.7\% vs. $92.7 \%)$, PPV (69.8\% vs. $69.6 \%)$, NPV (69.2\% vs. $69.2 \%)$ and accuracy ( $84 \%$ vs. $82.6 \%)$ of clinical diagnosis versus MRI for lateral meniscal lesions were the same. Rayan et al. analyzed 87 patients with meniscal lesions. They conclude that clinical examination had better sensitivity ( $86 \%$ vs. $76 \%$ ), specificity $(73 \%$ vs. $52 \%)$ and diagnostic accuracy $(79 \%$ vs. $63 \%$ ) in comparison to MRI for diagnosis medial meniscal lesions. In lateral meniscal lesions sensitivity (56\% vs. $61 \%$ ), specificity (95\% vs. $92 \%$ ) and diagnostic accuracy $(85 \%$ vs. $85 \%)$ were almost the same (19).

Rose et al. refer similar results in accuracy between clinical examination and MRI. Diagnostic accuracy for medial meniscal lesions was $82 \%$ vs. $75 \%$, and for lateral meniscal lesions $76 \%$ vs. $69 \%$ (20). Kocabey et al. and Bohnsack et al. stated that clinical examination is as accurate as MRI in the skilled orthopedic surgeon's hands and MRI should be reserved for more complicated and confusing cases $(21,22)$.

Mohan et al. reported accuracy of clinical diagnosis of $88 \%$ for medial meniscal lesions and $92 \%$ accuracy for lateral meniscal lesions (23).
Dutka $\mathrm{J}$ et al. reported of 113 patients who had better sensitivity of MRI in comparison to clinical examination for medial meniscal tears $(88 \%$ vs. $65 \%)$ and for lateral meniscal tears (44\% vs. 38\%) (24).

Hardy et al. refer sensitivity, specificity and accuracy of MRI diagnosis $(90 \%, 59 \%, 76 \%)$ in comparison to clinical diagnosis $(93 \%, 55 \%, 73 \%)(25)$.

Miller stated that accuracy of clinical diagnosis of meniscal lesions was $80.7 \%$ in comparison with accuracy of MRI diagnosis $73.7 \%$ (26).

Some authors analyze only the accuracy of MRI in comparison to arthroscopy. Their results were as follows: Aydingoz et al. report $90 \%$ sensitivity of MRI in detection of bucket handle lesions of meniscus. Cellar et al. refer of high sensitivity of MRI (92\%) for medial meniscal lesions and $70 \%$ sensitivity of MRI for lateral meniscal lesions $(27,28)$.

In our study the accuracy of clinical diagnosis compared with the accuracy of MRI diagnosis for ACL injuries were higher $(91.3 \%$ vs. $81.4 \%)$. Sensitivity, specificity and accuracy were $83.3 \%, 97.4 \%, 91.3 \%$ of the anterior drawer test, $69.4 \%, 98.8 \%, 86.95 \%$ of the Lachman test and $56.5 \%, 98.8 \%, 81.16 \%$ of the pivot shift test.

Dutka et al. found better sensitivity values of clinical examination for injuries of the anterior cruciate ligament (86\%) versus MR sensitivity (80\%) (24).

Esmaili Jah et al. reported that clinical examination was accurate in $91.4 \%$, and MRI in $88.5 \%$ of anterior cruciate ligament injuries (29).

Analysis of the clinical tests for ACL rupture was made by van Eck CF et al. Sensitivity was $38 \%$ and specificity $81 \%$ of the anteriordrawertest; sensitivity of the Lachman test was $81 \%$ and the specificity $81 \%$ and sensitivity of the pivot shift test was $28 \%$ and the specificity $81 \%$. The authors concluded that the Lachman test had the highest sensitivity for diagnosing an acute, complete ACL rupture (30).

Jain et al. presented the sensitivity of the anterior drawer test, the Lachman test and the pivot shift test and the results were $89.3 \%, 78.6 \%$ and $75 \%$, respectively (31).

In the study of Kim SJ, Kim HK comprising 147 patients, the anterior drawer test was positive in $79.6 \%$, the Lachman test was positive in $98.6 \%$, and the pivot shift test was positive in $89.8 \%$ of patients (32).

Some authors had equal or better results using MRI for diagnosis ACL injuries in comparison with clinical examinations.

Rose et al. obtained similar results in accuracy between clinical examination and MRI. Diagnostic accuracy for ACL tears was $99 \%$ vs. $98 \%$ (20).

Kocabey et al. stated that the accuracy of the clinical examination and MRI evaluation was equal in diagnosing ACL ruptures (21). 
Rayan et al. analyzed 26 patients with ACL injuries. They concluded that clinical examination versus MRI had almost the same sensitivity $(77 \%$ vs. $81 \%$, respectively), specificity (100\% vs. 96\%), positive predictive value (100\% vs. $81 \%$ ), negative predictive value (95\% vs. 95\%), and diagnostic accuracy (93\% vs. 96\%) (19).

The study of Laoruengthana et al. analyzing 50 patients showed that sensitivity, specificity, accuracy and negative predictive value (NPV) of MRI in detecting the complete tear of the ACL injury were $90.9 \%$, $84.6 \%, 88.6 \%$ and $84.6 \%$, respectively (33).

Ruth Crawford found MRI to be highly accurate in diagnosing anterior cruciate ligament (ACL) tears. It is the most appropriate screening tool before therapeutic arthroscopy. It is preferable to diagnostic arthroscopy in most patients because it avoids the surgical risks of arthroscopy (9).

In our study the sensitivity $(83.3 \%$ vs. $71 \%)$, specificity $(97.4 \%$ vs. $89.7 \%)$, positive predictive values $(96.2 \%$ vs. $84.6 \%)$ and negative predictive values $(88.4 \%$ vs. $79.5 \%$ ) of clinical diagnosis of ACL tears were better in comparison to MRI diagnosis. Diagnostic accuracy of clinical diagnosis was higher in comparison to MRI for ACL injuries (91.3\% vs. 81.4\%) (10).

We have better results for sensitivity $(91.8 \%$ vs. $79.6 \%)$, specificity (70\% vs. 57.1\%), PPV (88.2\% vs $81.3 \%)$, NPV (77.8\% vs $54.5 \%)$ and accuracy $(85.5 \%$ vs. $72.8 \%$ ) of clinical diagnosis versus MRI for articular cartilage lesions.

Gelb et al. evaluated articular surface damage. They said that the predictive value of positive tests was $100 \%$ for clinical assessment and $33 \%$ for the magnetic resonance imaging. They conclude that magnetic resonance imaging is overused in the evaluation of knee disorders and not a cost-effective method for evaluating injuries when compared with a skilled examiner (34).

Dutka et al. refer better sensitivity (51\% vs. 32\%) and specificity (100\% vs. 97\%) values of clinical examination for chondral injuries versus MRI (24).

Cellar et al. reported that sensitivity, specificity and accuracy of MRI in detecting articular chondral lesions, were $45 \% .87 \%$ and $60 \%$ (28).

In our study sensitivity ( $91.8 \%$ vs. $79.6 \%)$, specificity (70\% vs. $57.1 \%$ ) and accuracy ( $85.5 \%$ vs. $72.8 \%)$ of clinical diagnosis versus MRI for cartilage lesions were better. Duc et al. reported MRI sensitivity, specificity, and accuracy for the two readers and the two evaluations ranged from $56 \%$ to $66 \%, 78 \%$ to $93 \%$ and $71 \%$ to $75 \%$, respectively (35).

Friemert et al. said that the role of MRI for the diagnosis of chondral lesions of the knee joint is still unclear. The sensitivity of the method ranges from $15 \%$ to $96 \%$. They concluded that MRI is suitable for the exclusion of cartilage lesions (36).
Munk et al. concluded that the clinical relevance of MRI in cartilage lesions was more doubtful. Because of that the combination of clinical and MRI findings would reduce the number of blank arthroscopies to 5\%. MRI is a valuable diagnostic tool, but arthroscopy still remains the gold standard for definitive diagnosis (37).

D'Erme et al. reported $81 \%$ sensitivity and $61 \%$ specificity of MRI diagnosis for cartilage lesions (38).

Kijwski et al. said that sensitivity, specificity, and accuracy of MR imaging for detecting cartilage lesions were $69.3 \%, 78.0 \%$, and $74.5 \%$ (39).

In our study, we have better results for sensitivity (91.8\% vs $79.6 \%)$, specificity (70\% vs $57.1 \%)$, PPV (88.2\% vs $81.3 \%)$, NPV (77.8\% vs $54.5 \%)$ and accuracy $(85.5 \%$ vs $72.8 \%)$ of clinical diagnosis versus MRI for articular cartilage lesions.

Diagnosis of intraarticular lesions of the knee is a complex process, which includes clinical examination and MRI of the injured knee. Sometimes MRI is used more frequently because it is a very precise method for visualization of the soft tissue. Nevertheless, MRI does not diminish the importance of orthopedic clinical examination as an indication for arthroscopy.

The study of Trieshmann et al. shows that MRI of the knee is a valuable tool for augmenting the diagnostic process. It is a cost-effective technique for avoiding unnecessary surgery and affects patient outcome by improving surgical decision (40).

\section{CONCLUSION}

In conclusion, carefully performed clinical examination can give better diagnosis of knee injuries in comparison to MRI diagnosis. Any experienced orthopedic surgeon can trust his/her clinical diagnosis as an indication for arthroscopy followed by surgical treatment. When the clinical diagnosis is established, without any doubts due to positivity of the clinical tests, the MRI is not essential. In suspected cases where there is a dilemma, MRI is very helpful in making decision for arthroscopy.

Diagnostic accuracy of clinical and MRI diagnosis in knee injuries is high. Their reliabilities in diagnosis of meniscal lesions, ACL tears and articular cartilage lesions are evident.
Abbreviations
MRI - magnetic resonance imaging
ACL - anterior cruciate ligament
PPV — positive predictive value
NPV - negative predictive value
LR+- likelihood ratio positive
LR- - likelihood ratio negative
AUC - area under the curve 


\title{
Sažetak
}

\section{KOMPARATIVNE ANALIZE DIJAGNOSTIČKIH METODA KORIŠĆENIH KOD PACIJENATA SA POVREDOM KOLENA}

\author{
Dzoleva-Tolevska Roza, ${ }^{1}$ Poposka Anastasika, ${ }^{1}$ Georgieva Daniela, ${ }^{1}$ \\ Bozinovski Zoran, ${ }^{1}$ Nanceva Jasminka, ${ }^{1}$ Gjoshev Stojan ${ }^{2}$ \\ ${ }^{1}$ Univerity Clinic for Orthopaedic Surgery, Skopje, R. Macedonia \\ ${ }^{2}$ University Clinic for Abdominal Surgery, University "Ss Cyril and Methodius", Skopje, R. Macedonia
}

Uvod: Ova studija analizira ulogu i značaj tri dijagnostičke metode (klinička dijagnoza, magnetna rezonanca (MR) i artroskopija), u postavljanju tačne dijagnoze povrede kolena. Cilj ove studije bio je utvrđivanje tačnosti pojedinačnog dijagnostičkog metoda, koristeći artroskopiju kao zlatni standard.

Materijal i metode: Ispitivali smo 70 pacijenata sa povredom kolena. Klinička dijagnoza je postavljena na osnovu istorije bolesti pacijenta i pozitivnih kliničkih testova na povrede meniskusa, ACL i artikularne hrskavice. Svi pacijenti su podvrgnuti MR snimanju na 1.5 T magnetu za MR dijagnozu. Ovo je praćeno artroskopijom, za postavljanje finalne dijagnoze.

Rezultati: Analizirali smo rezultate kliničkih testova povreda meniskusa, ligamenata i artikularne hrskavice pacijenata u obe grupe. Validnost kliničkih testova bila je poređena sa rezultatima dobijenim sa MR i artroskopijom. Tačnost kliničke dijagnoze poređena sa

\section{REFERENCES}

1. Solomon DH, Simel DL, Bates DW, Katz JN, Schaffer JL. The rational clinical examination. Does this patient have a torn meniscus or ligament of the knee? Value of the physical examination. JAMA. 2001; 286(13): 1610-20.

2. Abdon P, Lindstrand A, Thorngren KG. Statistical evaluation of the diagnostic criteria for meniscal tears. Int Orthop. 1990; 14(4): 341-5.

3. von Engelhardt LV, Kraft CN, Pennekamp PH, Schild $\mathrm{HH}$, Schmitz A, von Falkenhausen M. The evaluation of articular cartilage lesions of the knee with a 3-Tesla magnet. Arthroscopy. 2007; 23(5): 496-502.

4. Noyes FR, Stabler CL. A system for grading articular cartilage lesions at arthroscopy. Am J Sports Med. 1989; 17(4): 505-13.

5. Reed ME, Villacis DC, Hatch GF 3rd, et al. 3.0-tesla MRI and arthroscopy for assessment of knee articular cartilage lesions. Orthopedics. 2013; 36(8): e1060-4.

6. Katz JW, Fingeroth RJ. The diagnostic accuracy of ruptures of the anterior cruciate ligament comparing the Lachman test, the anterior drawer sign, and the pivot shift test in acute and chronic knee injuries. Am J Sports Med. 1986; 14(1): 88-91.

7. Unay K, Akcal MA, Gokcen B, Akan K, Esenkaya I, Poyanl2 O. The relationship between intra-articular meniscal, chondral, and ACL lesions: finding from 1,774 knee arthroscopy patients and evaluation by gender. Eur J OrthopSurgTraumatol. 2014; 24(7): 1255-62.
MR dijagnozom za povrede medijalnog lemniskusa (69.6\% vs. $68.5 \%)$ i lateralnog ( $84 \%$ vs. $82.6 \%)$ bila je skoro identična. Tačnost kliničke dijagnoze poređena sa tačnosti MR dijagnoze za ACL povrede bila je viša (91.3\% vs. $81.4 \%)$. Tačnost kliničke dijagnoze prema MR dijagnozi povrede artikularne hrskavice $(85.5 \%$ vs. $72.8 \%$ ) išla je korist kliničkom postavljanju dijagnoze.

Zaključak: Potvrđivanje validnosti i značaja kliničke dijagnoze u ovoj studiji je rezultat korišćenja standardnih kliničkih znaka i testova, koji su fundamentalni u postavljanju kliničke dijagnoze povrede kolena. MR je dijagnostička procedura, koja obogaćuje dijagnostički proces. Artroskopija je definisana kao superiorni dijagnostički metod, kao i za zlatni standard, korišćen za upoređivanje tačnosti druga dva dijagnostička metoda.

Ključne reči: povreda kolena, kliničko ispitivanje, magnetna rezonanca, artroskopija.

8. Kostov H, Kostova E. Comparison of clinical and arthroscopic findings in meniscal tears. Sanamed. 2014; 9(1): 25-30.

9. Yan R, Wang H, Yang Z, Ji ZH, Guo YM. Predicted probability of meniscus tears: comparing history and physical examination with MRI. Swiss Med Wkly. 2011; 141: w13314.

10. Crawford R, Walley G, Bridgman S, Maffulli N. Magnetic resonance imaging versus arthroscopy in the diagnosis of knee pathology, concentrating on meniscal lesions and ACL tears: a systematic review. Br Med Bull. 2007; 84(1): 5-23.

11. von Engelhardt LV, Raddatz M, Bouillon B, et al. How reliable is MRI in diagnosing cartilaginous lesions in patients with first and recurrent lateral patellar dislocations? BMC Musculoskelet Disord. 2010; 11:149.

12. Cameron ML, Briggs KK, Steadman JR. Reproducibility and reliability of the outerbridge classification for grading chondral lesions of the knee arthroscopically. Am J Sports Med. 2003; 31(1): 83-6.

13. Ghodadra N, Mall NA, Karas V, et al. Articular and meniscal pathology associated with primary anterior cruciate ligament reconstruction. J Knee Surg. 2013; 26(3): 185-93.

14. Borchers JR, Kaeding CC, Pedroza AD, et al. Intra-articular findings in primary and revision anterior cruciate ligament reconstruction surgery: a comparison of the MOON and MARS study groups. Am J Sports Med. 2011; 39(9): 1889-93.

15. Munshi M, Davidson M, MacDonald PB, Froese W, Sutherland $\mathrm{K}$. The efficacy of magnetic resonance imaging in acute knee injuries. Clin J Sport Med. 2000; 10(1): 34-9. 
16. Strauss EJ, Fonseca LE, Shah MR, Yorum T. Management of focal cartilage defects in the knee - Is ACI the answer? Bull NYU Hosp Jt Dis.2011; 69(1): 63-72.

17. Falah M, Nierenberg G, Soudry M, Hayden M, Volpin G. Treatment of articular cartilage lesions of the knee. Int Orthop. 2010; 34(5): 621-30.

18. Frobell RB, Roos EM, Roos HP, Ranstam J, Lohmander LS. A randomized trial of treatment for acute anterior cruciate ligament tears. N Engl J Med. 2010; 363(4): 331-42.

19. Rayan F, Bhonsle S, Shukla DD. Clinical, MRI, and arthroscopic correlation in meniscal and anterior cruciate ligament injuries. Int Orthop. 2009; 33(1): 129-32.

20. Rose NE, Gold SM. A comparison of accuracy betwee$\mathrm{n}$ clinical examination and magnetic resonance imaging in the diagnosis of meniscal and anterior cruciate ligament tears. Arthroscopy. 1996; 12(4): 398-405.

21. Kocabey Y, Tetik O, Isbell WM, Atay OA, Johnson DL. The value of clinical examination versus magnetic resonance imaging in the diagnosis of meniscal tears and anterior cruciate ligament rupture. Arthroscopy. 2004; 20(7): 696-700.

22. Bohnsack M, Rühmann O, Sander-Beuermann A, Wirth CJ. Comparison of clinical examination with NMR spectroscopy in the diagnosis of meniscal lesions in daily practice. $\mathrm{Z}$ Orthop Ihre Grenzgeb. 1999; 137(1): 38-42.

23. Mohan BR, Gosal HS. Reliability of clinical diagnosis in meniscal tears. IntOrthop. 2007; 31(1): 57-60.

24. Dutka J, Skowronek M, Skowronek P, Dutka L. Arthroscopic verification of objectivity of the orthopaedic examination and magnetic resonance imaging in intra-articular knee injury. Retrospective study. Wideochir Inne Tech Malo Inwazyjne. 2012; 7(1): 13-8.

25. HardyJC., Evangelista GT, Grana WA, Hunter RE. Accuracy of magnetic resonance imaging of the knee in the community setting. Sports Health. 2012; 4(3): 222-31.

26. Miller GK. A prospective study comparing the accuracy of the clinical diagnosis of meniscus tear with magnetic resonance imaging and its effect on clinical outcome. Arthroscopy. 1996; 12(4): 406-13.

27. Aydingöz U, Firat AK, Atay OA, Doral MN. MR imaging of meniscal bucket-handle tears: a review of signs and their relation to arthroscopic classification. Eur Radiol. 2003; 13(3): 618-25.

28. Cellar R, Sokol D, Lacko M, Stofta S, Gharaibeh A, Vasko G. Magnetic resonance imaging in the diagnosis of intra-articular lesions of the knee. Acta Chir Orthop Traumatol Cech. 2012; 79(3): 249-54.

\author{
Correspondence to/ Autor za korespondenciju \\ Roza Dzoleva Tolevska, MD, PhD \\ Univerity Clinic for Orthopaedic Surgery, Skopje \\ R. Macedonia \\ e-mail: dzoleva@yahoo.com \\ phone: +38970 555656
}

29. Esmaili Jah AA, Keyhani S, Zarei R, Moghaddam AK. Accuracy of MRI in comparison with clinical and arthroscopic findings in ligamentous and meniscal injuries of the knee. Acta Orthop Belg. 2005; 71(2): 189-96.

30. van Eck CF, van den Bekerom MP, Fu FH, Poolman RW, Kerkhoffs GM. Methods to diagnose acute anterior cruciate ligament rupture: a meta-analysis of physical examinations with and without anaesthesia. Knee Surg Sports Traumatol Arthrosc. 2013; 21(8): 1895-903.

31. Jain DK, Amaravati R, Sharma G. Evaluation of the clinical signs of anterior cruciate ligament and meniscal injuries. Indian J Orthop. 2009; 43(4): 375-8.

32. Kim SJ, Kim HK. Reliability of the anterior drawer test, the pivot shift test, and the Lachman test. Clin Orthop Relat Res. 1995; (317): 237-42.

33. Laoruengthana A, Jarusriwanna A. Sensitivity and specificity of magnetic resonance imaging for knee injury and clinical application for the Naresuan University Hospital. J Med Assoc Thai. 2012; 95(Suppl 10): S151-7.

34. Gelb HJ, Glasgow SG, Sapega AA, Torg JS. Magnetic resonance imaging of knee disorders. Clinical value and cost-effectiveness in a sports medicine practice. Am J Sports Med. 1996; 24(1): 99-103.

35. Duc SR, Koch P, Schmid MR, Horger W, Hodler J, Pfirrmann CW. Diagnosis of articular cartilage abnormalities of the knee: prospective clinical evaluation of a 3D water-excitation true FISP sequence. Radiology. 2007; 243(2): 475-82.

36. Friemert B, Oberländer Y, Schwarz W, et al. Diagnosis of chondral lesions of the knee joint: can MRI replace arthroscopy? A prospective study.Knee Surg Sports Traumatol Arthrosc. 2004; 12(1): 58-64.

37. Munk B, Madsen F, Lundorf E, et al. Clinical magnetic resonance imaging and arthroscopic findings in knees: a comparative prospective study of meniscus anterior cruciate ligament and cartilage lesions. Arthroscopy. 1998; 14(2): 171-5.

38. D’Erme M, Ventura M, Di Giacomo G, Pasquali Lasagni M. Magnetic resonance and arthroscopy of the knee. A double-blind study in 40 patients. Radiol Med. 1992; 84(5): 553-6.

39. Kijowski R, Blankenbaker DG, Davis KW, Shinki K, Kaplan LD, De Smet AA. Comparison of 1.5- and 3.0-T MR imaging for evaluating the articular cartilage of the knee joint. Radiology. 2009; 250(3): 839-48.

40. Trieshmann HW Jr, Mosure JC. The impact of magnetic resonance imaging of the knee on surgical decision making. Arthroscopy. 1996; 12(5): 550-5. 